\title{
Cell Wall Characteristics of a Maize Mutant Selected for Decreased Ferulates
}

\author{
Ronald D. Hatfield ${ }^{*}$, Hans Jung ${ }^{2}$, Jane M. Marita ${ }^{1}$, Hoon Kim ${ }^{3}$ \\ ${ }^{1}$ USDA-Agricultural Research Service, U.S. Dairy Forage Research Center, Madison, WI, USA \\ ${ }^{2}$ USDA-Agricultural Research Service, Plant Science Research Unit, St. Paul, MN, USA \\ ${ }^{3}$ Great Lakes Bioenergy Research Center, University of Wisconsin, Madison, WI, USA \\ Email: *Ronald.Hatfield@ars.usda.gov
}

How to cite this paper: Hatfield, R.D., Jung, H., Marita, J.M. and Kim, H. (2018) Cell Wall Characteristics of a Maize Mutant Selected for Decreased Ferulates. American Journal of Plant Sciences, 9, 446-466. https://doi.org/10.4236/ajps.2018.93034

Received: January 22, 2018

Accepted: February 23, 2018

Published: February 26, 2018

Copyright ( $) 2018$ by authors and Scientific Research Publishing Inc. This work is licensed under the Creative Commons Attribution International License (CC BY 4.0).

http://creativecommons.org/licenses/by/4.0/

(c) (i) Open Access

\begin{abstract}
The cross-linked nature of plant cell walls provides structural integrity for continued growth and development, but limits degradation and utilization by ruminants. In grasses a major cross-linking component is ferulic acid that is incorporated into cell walls as an ester linked residue on arabinoxylans. Ferulates can become coupled to each other and to lignin forming a highly cross-linked matrix of carbohydrates and lignin. Seedling ferulate ester mutants ( $s f e$ ) were produced in maize using the transposon system and evaluated in feeding trials. The work described here was undertaken to characterize changes in the ferulate cross-linked nature as well as other components of the corn cell wall matrix in leaf, sheath and stem tissues. Total ferulates decreased modestly due to the mutation and were more apparent in leaf tissue $(16 \%$ $18 \%)$ compared to sheath ( +5 to $-6 \%$ change) and stem ( $8 \%-9 \%$ decrease). The most significant changes were in the ether linked ferulates to lignin, both monomer and dehydrodiferulates ( $14 \%$ to $38 \%$ decrease). Other characteristics of the cell wall (lignin, neutral sugar composition) also showed modest changes. The change in total ferulates was modest, but led to improved animal performance. These findings suggest that relatively small changes can have a significant impact upon how well plant materials can be broken down and utilized by ruminants such as dairy cows.
\end{abstract}

\section{Keywords}

Hydroxycinnamates, Ferulates, Ferulate Dimers, Cell Wall, Digestibility

\section{Introduction}

Forages, including maize (Zea mays L.) silage, are key components of diets for 
ruminants. There is a renewed interest in forages especially in energy dense diets such as those required for high producing dairy cows. This is primarily due to the increase in grain prices partially driven by the creation of new markets especially for corn grain as a primary feedstock for ethanol production. With increasing demands for bioenergy liquid fuels either from grain or from plant vegetative biomass there is competition for productive land areas among needs for human food and fiber, animal feed needs, and now biomass for bioenergy. To meet these demands it is critical we maximize the returns from crops grown on each land unit.

In grasses, it has been shown that ferulates (defined here as all detectable ferulate compounds: monomers and dimers, ester and/or ether linked) are major factors in determining the extent of cross-linking within the cell wall matrix. Ferulate monomers (FA, referring to only monomers) are shuttled into the growing cell wall matrix esterified primarily to arabinosyl side chains of arabinoxylans [1] [2] [3]. Once incorporated in the cell wall, FA can undergo radical mediated cross-coupling reactions [4] [5] to form an array of dehydrodiferulates (dimers DFA). It has also been shown that FA can undergo additional cross-linking to form dehydrotriferulates and dehydrotetraferulates in some cereals and grains [6] [7]. In the wall, ferulates can undergo further radical mediated cross-coupling reactions with growing lignin polymers [8] [9] [10]. The outcome is a matrix involving both carbohydrates and lignin that is cross-linked. Degradation of the walls is limited by degree of ferulate cross-linking not only at the DFA level, but even more with the addition of cross coupling to lignin [11] [12]. Because of the direct impact of ferulate cross-linking on cell wall degradation, limiting the degree of ferulate incorporation should result in increased wall degradation.

Casler and Jung [13] [14] have shown that genetic selection for reduced ferulates etherified to lignin could be a strategy for improving cell wall degradation. Utilizing divergent selection techniques, they were able to show selection for decreased cross-linking in C3 grasses could improve in vitro digestibility. Although this is a feasible strategy, progress is slow and limited due to the nature of the chemical assays needed to measure the degree of ferulate cross-linking in grass cell walls. Molecular approaches to identify the correct gene that encodes the appropriate transferase have been tried in rice and Brachypodium [15] [16]. This work supports the hypothesis by Mitchell et al. [17] that CoA-acyl transferases in the PF02458 family are the best candidates for feruolylation of arabinoxylans. Jung and Phillips [18] used a transposon system in maize to identify a mutant with decreased ferulate ester incorporation into corn cell walls of seedling leaves. Backcross lines were developed and tested for decreased ferulate incorporation (sfe mutation). Near-isogenic lines of the sfe maize mutant were used in feeding trials of dairy cows with results indicating a significant gain in digestibility and animal performance without sacrificing total biomass production [18] [19]. Changes in total FA (monomer ester and ether linked) were decreased, but not 
by large amounts. This may be expected because ferulates play a crucial role in cell wall organization and strength. Too great of a reduction, inferulates may result in poor cell wall stability leading to poor survival.

In the earlier plot trial evaluation of the sfe mutation [18], near-infrared reflectance spectroscopy was used to estimate cell wall composition because sample numbers were too large for wet chemistry analysis of all samples $(\mathrm{N}=432)$. Also, only ferulate monomers were quantified in the previous study. The current study was undertaken to more completely characterize the changes in ferulate incorporation into corn cell walls due to the sfe mutation using direct measurements. Of particular interest were the DFA and ether-linked ferulates that indicate the extent of cross-linking to lignin. These data provide a more complete picture of the cross-linked nature of maize cell walls and how these components impact animal performance.

\section{Materials and Methods}

\subsection{Plant Materials}

Near-isogenic lines of the putative sfe maize mutant were compared to the parental inbred W23 to determine cell wall characteristics. A description of how the sfe mutant was identified and development of the near-isogenic lines was provided by Jung and Phillips [18]. Two sfe lines (W23sfe4 and W23sfe21 independent mutant lines) were chosen for study because they had the greatest impact on ferulate ether concentration and cell wall degradability in the plot trial of the four mutant lines examined [18] and these two lines were subsequently evaluated in animal feeding trials [19]. In brief, the W23 and W23sfe lines were grown at St. Paul and Rosemount, MN (plant hardiness zone 4b, cultivation conditions as described by Jung and Phillips, [18]) during the 2005 and 2006 growing seasons in replicated $(\mathrm{N}=4)$ field trials. Plants were harvested at the silage maturity stage, separated into leaf blade, sheath, and stem, dried, and ground. For the current study, equal amounts of dried and ground material from each field plot, location, and year $(\mathrm{N}=16)$ for every maize line was combined to create individual leaf blade, sheath, and stem samples of W23, W23sfe4, and W23sfe21. Statistical analysis was limited to standard deviations of the mean from replicate analyses of pooled samples. Standard errors were calculated for the duplicate laboratory analyses done on each sample. For comparison of W23 with the two mutant lines within plant parts different letters indicate differences at the $\mathrm{p}<0.1$ level.

\subsection{Preparation of Tissue Materials for Analysis}

Ground samples were processed following the procedure of Hatfield et al. [20] [21] with modifications [22]. Briefly samples were buffer (50 mM TRIS pH 6.7), washed before incubated in a $90^{\circ} \mathrm{C}$ water bath for $2 \mathrm{~h}$ followed with addition of amylase (Sigma A3403 $10 \mathrm{U} /$ tube) and amyloglucosidase (Fluka $1011510 \mathrm{U} /$ tube). Tubes were transferred to a $55^{\circ} \mathrm{C}$ water bath for incubation $(2 \mathrm{~h})$ to remove 
starch. Ethyl alcohol (EtOH, 95\%) was added to each tube to make the final EtOH concentration $80 \%$. Destarched samples were washed with a solvent series composed of: $80 \% \mathrm{EtOH}(2 \mathrm{X})$, chloroform: methanol 2:1 ( $\left.\mathrm{CHCl}_{3}: \mathrm{MeOH} ; 1 \mathrm{X}\right)$, and acetone (3X) to remove cytoplasmic contaminants. Each wash included 30 min of shaking (in horizontal position at $150 \mathrm{rpm}$ ) at $37^{\circ} \mathrm{C}$, centrifugation $(25,000 \mathrm{xg}$ for $15 \mathrm{~min})$ and solvent removal. The final retained insoluble residues, mainly cell walls, were allowed to air dry under the hood and used for structural analysis.

\subsection{Structural Analysis of Leaf, Sheath, Stem}

Carbohydrate analyses. Cell wall residues were dried in a $55^{\circ} \mathrm{C}$ oven prior to hydrolysis [23] as modified by Hatfield [24], derivatization [25], and analyzed by FID-GLC (Supelco SPB-225 column $30 \mathrm{~m} \times 0.25 \mathrm{~mm}$ with 0.25 micron film thickness). Total uronosyls were measured according to the methods described by Hatfield [22].

Lignin determination. Lignin concentrations inisolated cell walls were determined using the acetyl bromide method as modified by Hatfield et al. [26] [27] Dried cell walls were accurately weighed ( $\sim 25 \mathrm{mg} / \mathrm{sample})$ into glass culture tubes $(16 \mathrm{~mm} \times 150 \mathrm{~mm}$, with Teflon lined caps) and acetyl bromide reagent (2.5 $\mathrm{mL}$ of $25 \%$ acetyl bromide in glacial acetic acid) added to each tube, tubes capped tightly and incubated for $2 \mathrm{~h}$ at $50^{\circ} \mathrm{C}$ in a dry block heater. Lignin extracts were subsampled and centrifuged at $17,000 \mathrm{xg}$ for $5 \mathrm{~min}$ at $24^{\circ} \mathrm{C}$ to clarify the reaction mixture. A $0.5 \mathrm{~mL}$ subsample was removed from the supernatant and combined with $9.5 \mathrm{~mL}$ of glacial acetic acid containing $2 \mathrm{M} \mathrm{NaOH}$ and 0.5 $\mathrm{M}$ hydroxylamine. Lignin extracts were scanned from 250 to $350 \mathrm{~nm}$ (Beckman DU-50) to determine peak absorbance at $280 \mathrm{~nm}$. The extinction coefficient for calculating lignin concentration was based on a purified $\mathrm{HCl}$-dioxane lignin isolated from corn stems [28].

Cell wall phenolics. Cell walls were analyzed for ester- and ether-linked phenolics using the procedure of Grabber et al. [5] [10] as modified by Hatfield [22]. Phenolics ( $p$-coumarates and monomers and dimers of ferulates) were identified and quantified as trimethylsilane derivatives (40 $\mu \mathrm{L}$ TMSI, Pierce and $10 \mu \mathrm{L}$ pyridine) using GLC-FID on a ZB-5ms column (Zebron; $30 \mathrm{~m} \times 0.25 \mathrm{~mm}, 0.25$ micron film). The GLC conditions were injector $315^{\circ} \mathrm{C}, 300^{\circ} \mathrm{C}$ detector, and a temperature program of $220^{\circ} \mathrm{C}$ for $1 \mathrm{~min}, 4^{\circ} \mathrm{C} \mathrm{min}^{-1}$ to $248,30^{\circ} \mathrm{C} \mathrm{min}{ }^{-1}$ to $300^{\circ} \mathrm{C}$ and hold for $20 \mathrm{~min}$.

\subsection{2-D NMR Analysis}

The whole plant cell wall gel-state samples for NMR experiments were prepared as described [29] [30]. Dried plant material was ground for $1 \mathrm{~min}$ in a Retsch MM400 mixer mill at $30 \mathrm{~Hz}$, using zirconium dioxide $\left(\mathrm{ZrO}_{2}\right)$ vessels $(10 \mathrm{ml})$ containing $\mathrm{ZrO}_{2}$ ball bearings $(2 \times 10 \mathrm{~mm})$. The ground cell walls are extracted with distilled water (ultra-sonication, $1 \mathrm{~h}$, three times) and $80 \%$ ethanol (ul- 
tra-sonication, $1 \mathrm{~h}$, three times). Isolated cell walls were dried and ball-milled using a Retsch PM100 planetary ball mill at $600 \mathrm{rpm}$, using $\mathrm{ZrO}_{2}$ vessels $(50 \mathrm{ml})$ containing $\mathrm{ZrO}_{2}$ ball bearings $(10 \times 10 \mathrm{~mm})$. Each sample $(100 \mathrm{mg})$ was ground for $25 \mathrm{~min}$ (interval: $5 \mathrm{~min}$, break: $5 \mathrm{~min}$, repeated $5 \mathrm{x}$ ). Cell walls were collected directly into NMR tubes and gels formed using DMSO- $\mathrm{d}_{6} /$ pyridine- $\mathrm{d}_{5}(4: 1)$.

NMR experiments for the whole plant cell wall gel-state samples were performed as described by Kim and Ralph [29]. NMR spectra are acquired on a Bruker Biospin (Billerica, MA) DMX $500 \mathrm{MHz}$ spectrometer fitted with a cryogenically cooled 5-mm TXI gradient probe with inverse geometry (proton coils closest to the sample). The central DMSO solvent peak is used as internal reference $(\delta \mathrm{C}$ $39.5, \delta \mathrm{H} 2.49 \mathrm{ppm})$. The ${ }^{13} \mathrm{C}-{ }^{1} \mathrm{H}$ correlation experiment is an adiabatic HSQC experiment (Bruker standard pulse sequence 'hsqcetgpsisp.2'; phase-sensitive gradient-edited-2D HSQC using adiabatic pulses for inversion and refocusing) [31]. HSQC experiments were carried out using the following parameters: acquired from 10 to $0 \mathrm{ppm}$ in $\mathrm{F} 2\left({ }^{1} \mathrm{H}\right)$ with 1000 data points (acquisition time 100 $\mathrm{msec}$ ), $200-0 \mathrm{ppm}$ in $\mathrm{F} 1\left({ }^{13} \mathrm{C}\right)$ with 320 increments (F1 acquisition time 6.3 $\mathrm{msec}$ ) of 32 scans with a $0.5 \mathrm{sec}$ interscan delay; the d24 delay is set to $0.89 \mathrm{~ms}$ $(1 / 8 \mathrm{~J}, \mathrm{~J}=145 \mathrm{~Hz})$. Processing uses typical matched Gaussian apodization in F2 and, squared cosine-bell and one level of linear prediction (32 coefficients) in F1. Volume integration of contours in HSQC plots uses Bruker's TopSpin 2.1 software.

\section{Results and Discussion}

In grasses, it is well established that ferulates play a pivotal role in cross-linking the cell wall matrix. Ferulates can form dehydrodiferulates (DFA) cross-linking primarily arabinoxylans [32] and recent work has shown ferulate trimers and tetramers are also possible within cell wall matrices [33]. Ferulates can also undergo radical mediated cross-coupling reactions to form a range of ferulatelignin monomer coupling products that further tie the wall matrix together (Figure 1). The more the matrix is cross-linked the less digestible it becomes [12]. Decreasing the level of ferulates incorporated into the cell wall matrix would theoretically decrease the amount of cross-coupling mediated by ferulates and increase cell wall digestibility. Earlier work by Grabber et al., using a cell wall model system based on corn cell cultures [11] [12]. These model studies demonstrated increased formation of DFA and incorporation into lignin changing the level of total cell wall matrix cross-linking impacted both rate and extent of cell wall degradation.

Development of the maize seedling ferulate ester ( $s f e)$ mutant was undertaken to generate plant materials with decreased ferulates incorporated into the cell wall matrix [18]. Maize mutant lines, W23sfe4 and W23sfe21, used in a feeding trial with dairy cows showed increased cell wall digestibility, intake, and milk production [19]. A comparison of inbred lines W23 with W23sfe mutant lines showed no impact of the sfe mutation on total biomass accumulation [18]. The 


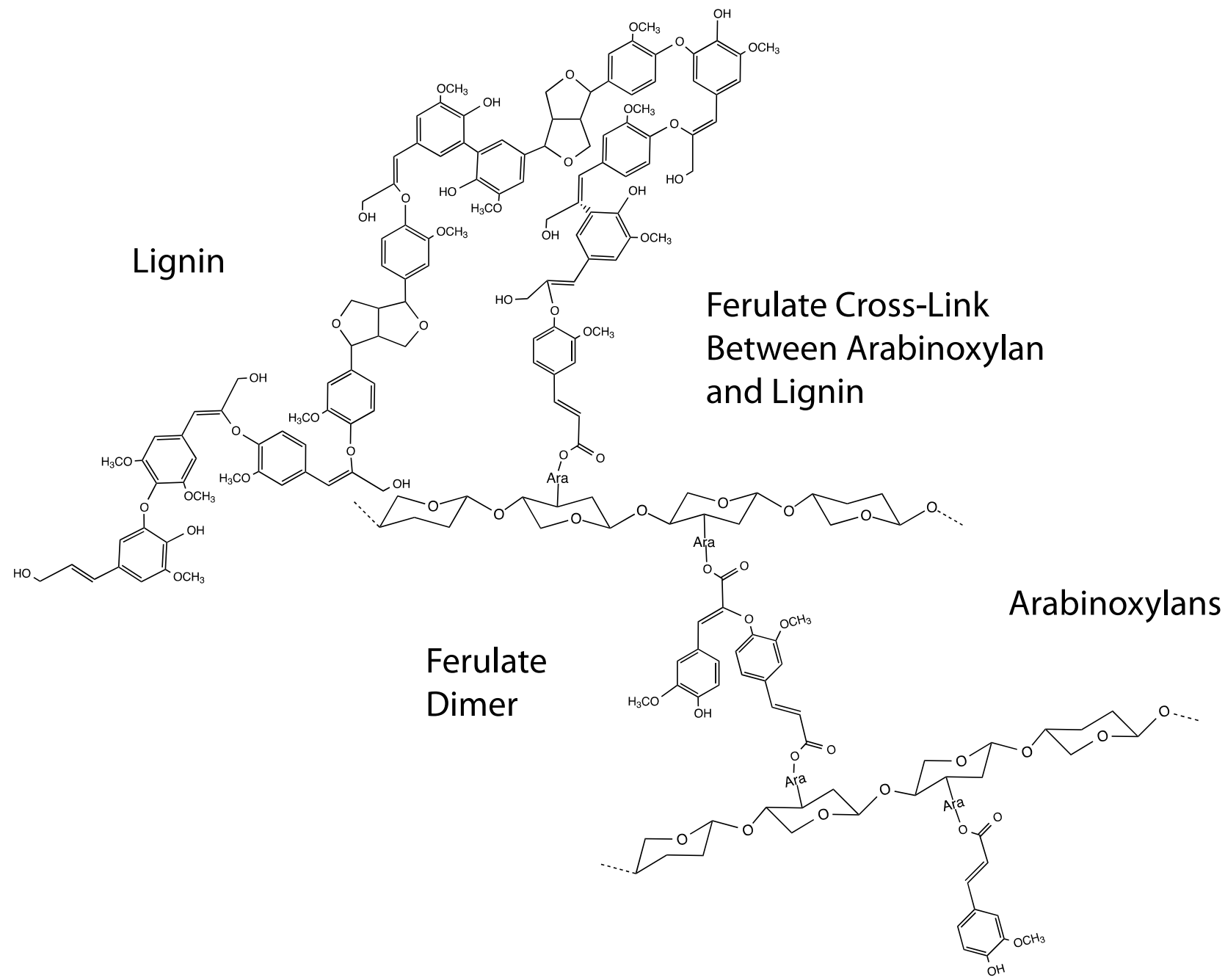

Figure 1. Illustration of cell wall model showing cross-linked nature due to the incorporation of ferulates into the wall matrix. Ferulate dimers cross-link arabinoxylans and ether linked ferulates link arabinoxylans to lignin.

present study was undertaken to determine detailed cell wall characteristics of leaf, sheath, and stems from mutant lines W23sfe4 and W23sfe21 as compared to the backcross parent line W23.

\subsection{Cell Wall Ferulates}

Chemical analyses of the major cell wall components are summarized in Table 1 including total ferulates (total ferulates refers to both monomers and dimers that make up the ester and ether linked components). Because the original mutant lines were selected for decreased ferulate levels one would expect to see lower total ferulates within the different cell wall tissues. There was a consistent decrease of approximately $20 \%$ when comparing W 23 to the two mutants W23sfe4 and W23sfe21, although analyses of the different maize tissues revealed that the degree of decrease in total ferulates was tissue dependent (Table 1). Maize stem tissues were similar to leaf tissue with consistently lower levels of total ferulates for W23sfe4 and W23sfe21; however, the magnitude was only about half that 
Table 1. Concentration (mean \pm 1 standard error) of acetyl bromide lignin (ABL), carbohydrates (CHO), and esterified and etherified $p$-coumarates $(p C A)$ and ferulates $(F A)$ in cell wall material from leaf blade, sheath, and stem mature stover fractions of the maize inbred line W23, and the near-isogenic low ferulate W23sfe4 and W23sfe21 mutant lines. ${ }^{\dagger}$

\begin{tabular}{|c|c|c|c|c|c|c|c|c|}
\hline \multirow[b]{2}{*}{ Line } & \multicolumn{3}{|l|}{ Plant } & \multicolumn{2}{|c|}{ Esters } & \multicolumn{2}{|c|}{$\underline{\text { Ethers }}$} & \multirow{2}{*}{ Total Ferulates } \\
\hline & Part & $\mathrm{ABL}$ & $\mathrm{CHO}$ & $p \mathrm{CA}^{\mathrm{a}}$ & $\mathrm{FA}^{\mathrm{b}}$ & $p \mathrm{CA}^{\mathrm{a}}$ & $\mathrm{FA}^{\mathrm{b}}$ & \\
\hline \multicolumn{9}{|c|}{ 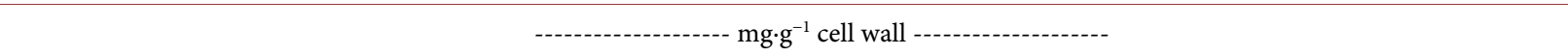 } \\
\hline W23 & leaf & $143 a \pm 5$ & $403 \pm 37$ & $4.83 a \pm 0.25$ & $4.68 \pm 0.18$ & $0.60 \pm 0.05$ & $2.73 \pm 0.01$ & $7.41 a^{c} 100 \%$ \\
\hline W23sfe4 & leaf & $130 \mathrm{~b} \pm 2$ & $410 \pm 6$ & $4.34 \mathrm{ab} \pm 0.17$ & $4.13 \pm 0.03$ & $0.52 \pm 0.08$ & $1.95 \pm 0.28$ & $6.08 \mathrm{~b} 82 \%$ \\
\hline W23sfe21 & leaf & $117 \mathrm{c} \pm 0$ & $457 \pm 9$ & $4.18 \mathrm{~b} \pm 0.15$ & $4.22 \pm 0.04$ & $0.49 \pm 0.04$ & $1.98 \pm 0.02$ & $6.20 \mathrm{~b} 84 \%$ \\
\hline W23 & sheath & $167 \mathrm{a} \pm 1$ & $552 \pm 10$ & $8.03 \pm 0.29$ & $7.98 \pm 0.22$ & $0.80 \pm 0.07$ & $3.04 \pm 0.10$ & $11.02 \mathrm{ab} 100 \%$ \\
\hline W23sfe4 & sheath & $160 \mathrm{~b} \pm 0$ & $534 \pm 5$ & $7.57 \pm 0.39$ & $7.59 \pm 0.46$ & $0.77 \pm 0.04$ & $2.79 \pm 0.18$ & $10.38 \mathrm{~b} 94 \%$ \\
\hline W23sfe 21 & sheath & $161 b \pm 5$ & $591 \pm 70$ & $7.73 \pm 0.20$ & $8.96 \pm 0.15$ & $0.76 \pm 0.08$ & $2.58 \pm 0.03$ & $11.54 \mathrm{a} 105 \%$ \\
\hline W23 & stem & $218 \pm 2$ & $565 \pm 38$ & $21.66 \pm \mathrm{ND}^{\ddagger}$ & $5.56 \pm \mathrm{ND}$ & $2.39 \pm \mathrm{ND}$ & $4.28 \pm \mathrm{ND}$ & $9.84100 \%$ \\
\hline W23sfe4 & stem & $206 \pm 2$ & $522 \pm 28$ & $21.32 \pm 0.04$ & $5.48 \pm 0.23$ & $2.22 \pm 0.15$ & $3.47 \pm 0.04$ & $8.9591 \%$ \\
\hline W23sfe21 & stem & $199 \pm 5$ & $573 \pm 24$ & $20.17 \pm 0.78$ & $5.80 \pm 0.20$ & $1.87 \pm 0.01$ & $3.27 \pm 0.16$ & $9.0792 \%$ \\
\hline
\end{tabular}

${ }^{\dagger}$ Samples were composites from the replicated field trial reported by Jung and Phillips (2010). Equal amounts of dried plant material for each maize line and plant part from each field plot $(\mathrm{N}=4)$, location $(\mathrm{N}=2)$, and year $(\mathrm{N}=2)$ were combined to create the samples analyzed in the current study. ${ }^{\text {*Standard }}$ errors were calculated for the duplicate laboratory analyses done on each sample. For comparison of W23 with the two mutant lines within plant parts different letters indicate differences at the $\mathrm{p}<0.1$ level. For W23 stem material, one of the replicate subsamples was lost during the analysis and, therefore, the mean is based on only one lab subsample analysis. For comparison of W23 with the two mutant lines within plant parts different letters indicate differences at the $\mathrm{p}<0.1$ level. ${ }^{\mathrm{a}} \mathrm{pCA}=\Sigma($ cis- $p \mathrm{CA}+$ trans- $p \mathrm{CA})$; ${ }^{\mathrm{b}}$ total $\mathrm{FA}=\Sigma($ cis-FA + trans-FA $+8-8 \mathrm{c}+8-8 \mathrm{nc}+8-5 \mathrm{nc}+8-O-4+8-5 \mathrm{benz}+\mathrm{t} 8-5 \mathrm{nc}+8-5 \mathrm{dc}+5-5)$; 'percent of total ferulates compared to W23. FA dimer nomenclature is as follows; $8-8 \mathrm{c}=8-8 \mathrm{cyclic} ; 8-8 \mathrm{nc}=8-8 \mathrm{non}-\mathrm{cyclic} ; 8-5 \mathrm{nc}=8-5 \mathrm{non}-\mathrm{cyclic} ; 8-O-4=$ 8-4 ether linked; 8-5benz $=8-5$ phenyl coumararan; $\mathrm{t} 8-5 \mathrm{nc}=$ trans-8-5 non-cyclic; $8-5 \mathrm{dc}=\mathrm{a}$ decomposition product of 8-5 cyclic compound upon alkaline treatment; 5-5 = both cis and trans forms of 5-5 coupled FA. See the experimental section of manuscript for official names and abbreviations.

seen in leaf tissue. For sheath tissues, there was no consistent change in total sheath tissue ferulates that could be attributed to the sfe mutation. Earlier work by Jung and Phillips indicated the leaf blade, but not sheath tissue, of line W23sfe21 had more esterified FA than W23 [18]. Part of the difference in the results of the current study and previous work resulted from the inclusion of DFA as part of the total ferulates measured. For ether-linked ferulates, those linked to both arabinoxylans and to lignin, there was an apparent decrease in all tissues (Table 1).

Ester linked DFA followed the same pattern as monomers (Table 2). Only the leaf tissues had a consistently lower amount of ester linked DFA. There were differences between ferulates that were ester linked and those that were ether linked. For W23sfe4 and W23sfe21 ester linked DFA showed a decrease in leaf tissues similar to FA, but sheath and stem were essentially unchanged ferulates (Table 2). Sheath tissues were an exception for the ester-linked DFA compared to the ester linked FA. The W23sfe4 and W23sfe21mutants actually contained higher levels of ester-linked FA compared to W23 line, but DFA decreased in W23sfe4 (approximately 20\%, Table 2). Ether linked FA showed a more prominent decrease within the tissue types compared to ester linked. Ester linked FA (monomers only) would have limited impact upon cell wall cross-linking, but 
Table 2. Comparison of maize tissues of w23, W23sfe4, and W23sfe21 for total ferulates extracted from cell walls of leaf, sheath, and stem. Ferulates are separated by linkage type (ester and ether linked) and into monomers and dehydrodiferulates. Percent change in ferulates is also shown in the table.

\begin{tabular}{|c|c|c|c|c|c|c|c|c|c|}
\hline \multirow[t]{3}{*}{ Line } & \multirow[t]{3}{*}{ Plant Tissue } & \multicolumn{5}{|c|}{ Ferulate Esters } & \multicolumn{3}{|c|}{ Ferulate Ethers } \\
\hline & & \multicolumn{8}{|c|}{$\mathrm{mg} \cdot \mathrm{g}^{-1}$ cell wall } \\
\hline & & Monomers & $\%$ of W23 & Dimers & \% W23 & Monomers & $\% \mathrm{~W} 23$ & Dimers & $\% \mathrm{~W} 23$ \\
\hline W23 & leaf & $3.55 \pm 0.18 \mathrm{a}$ & 100 & $1.13+0.01 \mathrm{a}$ & 100 & $2.14 \pm 0.16 \mathrm{a}$ & 100 & $0.61 \pm 0.11$ & 100 \\
\hline W23sfe4 & leaf & $3.13 \pm 0.13 b$ & 88 & $1.00 \pm 0.08 \mathrm{ab}$ & 88 & $1.57 \pm 0.31 b$ & 73 & $0.38 \pm 0.02$ & 62 \\
\hline W23sfe21 & leaf & $3.30 \pm 0.11 \mathrm{ab}$ & 93 & $0.92 \pm 0.05 b$ & 81 & $1.57 \pm 0.11 b$ & 73 & $0.41 \pm 0.09$ & 67 \\
\hline W23 & sheath & $5.22 \pm 0.13 b$ & 100 & $2.77 \pm 0.07 \mathrm{a}$ & 100 & $2.38 \pm 0.20$ & 100 & $0.67 \pm 0.21$ & 100 \\
\hline W23sfe4 & sheath & $5.29 \pm 0.13 b$ & 101 & $2.30 \pm 0.21 b$ & 83 & $1.98 \pm 0.10$ & 83 & $0.81 \pm 0.20$ & 121 \\
\hline W23sfe21 & sheath & $6.19 \pm 0.17 \mathrm{a}$ & 118 & $2.78 \pm 0.01$ & 100 & $2.02 \pm 0.19$ & 85 & $0.55 \pm 0.16$ & 82 \\
\hline W23 & stem & $4.53 \pm 0 . \mathrm{D}$ & 100 & $1.04 \pm \mathrm{ND}$ & 100 & $3.39 \pm \mathrm{NDa}$ & 100 & $0.89 \pm \mathrm{ND}$ & 100 \\
\hline W23sfe4 & stem & $4.40 \pm 0.08$ & 97 & $1.08 \pm 0.10$ & 104 & $2.90 \pm 0.22 \mathrm{ab}$ & 86 & $0.57 \pm 0.19$ & 64 \\
\hline $\mathrm{W} 23 s f e 21$ & stem & $4.70 \pm 0.16$ & 104 & $1.10 \pm 0.03$ & 106 & $2.70 \pm 0.01 \mathrm{~b}$ & 80 & $0.57 \pm 0.12$ & 64 \\
\hline
\end{tabular}

For comparison of W23 with the two mutant lines within plant parts different letters indicate differences at the $\mathrm{p}<0.1$ level.

could slow cell wall degradation because an esterase would be needed to remove the FA to allow complete breakdown of the arabinoxylan polysaccharides.

In addition to the simple ester and ether linked FA, ester and ether linked DFA were also analyzed in detail (Table 3 and Table 4). Eight different DFAs were evaluated in each of the plant materials and tissue types (Figure 2 chemical structures of ferulate dimers, for a more complete description of ferulate dimer formation see Ralph et al. [4]. There was variability in the concentration of individual types of DFA (i.e., 8-8nc vs $8-8 \mathrm{c}$ vs8-5nc and so on) in the different tissues and for W23 compared to the W23sfe mutant lines. The DFA forms 8-8c, 8-O-4, and 5-5 tended to be the most predominate among the ester linked, and these are frequently found as the most abundant in grass cell walls [4] [34] [35]. The formation of specific types of DFA probably had more to do with the proximal location to one another as opposed to a predetermined need for a given DFA [36]. The total ester linked DFA did not have a consistent pattern of lower concentrations in the mutant lines. However, for ether linked DFA there was a more consistent pattern of decreased concentrations due to the mutation (Table 4). For stem and leaf tissues this decrease averaged 35\% (range of 33\% to 37\%). Sheath tissues had less consistent results for the sfe mutation. Increased amounts of cross-linking within the sheath tissue may be expected due to the key role it plays protecting the stem while it develops and is the basis for support of the developing leaf. In terms of the types of ether linked DFA present, the most predominate forms were $5-5>8-5 \mathrm{nc}>8-5 \mathrm{benz}>8-O-4>8-8 \mathrm{c}$. This was a different pattern than seen for the ester linked DFA. The predominance of DFA linkage type whether ester linked or ether linked seemed to vary with the tissue type (Table 3 vs Table 4). This may be an indication that formation of linkages was 
Table 3. Concentration (mean \pm 1 standard error) of esterified diferulates in cell wall material from leaf blade, sheath, and stem mature stover fractions of the maize inbred line W23, and the near-isogenic low ferulate W23sfe4 and W23sfe21 mutant lines. ${ }^{\dagger}$

\begin{tabular}{|c|c|c|c|c|c|c|c|c|c|c|}
\hline \multirow[b]{2}{*}{ Line } & \multirow{2}{*}{$\begin{array}{c}\text { Plant } \\
\text { Part }\end{array}$} & \multicolumn{9}{|c|}{ Esterified Diferulates } \\
\hline & & $8-8 \mathrm{nc}$ & $8-8 c$ & $8-5 n c$ & $8-O-4$ & 8-5benz & $t 8-5 \mathrm{nc}$ & $8-5 \mathrm{dc}$ & $5-5$ & Total \\
\hline & & \multicolumn{9}{|c|}{ - } \\
\hline \multirow{2}{*}{ W23 } & \multirow{2}{*}{ leaf } & 0.030 & 0.265 & 0.126 & 0.166 & $0.306 a$ & 0.038 & $0.110 \mathrm{a}$ & 0.091 & $1.130 \mathrm{a}$ \\
\hline & & \pm 0.003 & \pm 0.005 & \pm 0.005 & \pm 0.010 & \pm 0.004 & \pm 0.001 & \pm 0.005 & \pm 0.006 & \pm 0 \\
\hline \multirow{2}{*}{ W23sfe4 } & \multirow{2}{*}{ leaf } & 0.036 & 0.177 & 0.149 & 0.154 & $0.260 \mathrm{ab}$ & 0.039 & $0.093 \mathrm{ab}$ & 0.096 & $1.002 \mathrm{ab}$ \\
\hline & & \pm 0.010 & \pm 0.055 & \pm 0.009 & \pm 0.009 & $\pm 0.010 \mathrm{~b}$ & \pm 0.004 & \pm 0.010 & \pm 0.004 & \pm 0.081 \\
\hline \multirow{2}{*}{ W23sfe 21} & \multirow{2}{*}{ leaf } & 0.033 & 0.232 & 0.075 & 0.142 & 0.239 & 0.028 & $0.084 \mathrm{~b}$ & 0.090 & $0.923 b$ \\
\hline & & \pm 0.012 & \pm 0.005 & \pm 0.071 & \pm 0.005 & \pm 0.031 & \pm 0.011 & \pm 0.001 & \pm 0.006 & \pm 0.054 \\
\hline \multirow{2}{*}{ W23 } & \multirow{2}{*}{ sheath } & 0.073 & 0.300 & $0.358 \mathrm{a}$ & 0.555 & 0.820 & 0.117 & 0.267 & $0.280 \mathrm{ab}$ & 2.767 \\
\hline & & \pm 0.012 & \pm 0.046 & \pm 0.008 & \pm 0.027 & \pm 0.078 & \pm 0.002 & \pm 0.008 & \pm 0.004 & \pm 0.069 \\
\hline \multirow{2}{*}{ W23sfe4 } & \multirow{2}{*}{ sheath } & 0.061 & 0.253 & $0.343 a$ & 0.448 & 0.601 & 0.097 & 0.261 & $0.237 \mathrm{~b}$ & 2.300 \\
\hline & & \pm 0 & \pm 0.006 & \pm 0.001 & \pm 0.078 & \pm 0.109 & \pm 0.021 & \pm 0.002 & \pm 0.004 & \pm 0.209 \\
\hline \multirow{2}{*}{ W23sfe21 } & \multirow{2}{*}{ sheath } & 0.066 & 0.284 & $0.430 \mathrm{~b}$ & 0.593 & 0.744 & 0.111 & 0.234 & $0.315 \mathrm{a}$ & 2.775 \\
\hline & & \pm 0.002 & \pm 0.005 & \pm 0.019 & \pm 0.003 & \pm 0.079 & \pm 0.026 & \pm 0.042 & \pm 0.035 & \pm 0.010 \\
\hline \multirow{2}{*}{ W23 } & \multirow{2}{*}{ stem } & 0.063 & 0.066 & 0.151 & $0.165 \mathrm{~b}$ & 0.344 & 0.050 & 0.122 & 0.074 & 1.035 \\
\hline & & $\pm \mathrm{ND}^{\ddagger}$ & $\pm \mathrm{ND}$ & $\pm \mathrm{ND}$ & $\pm \mathrm{ND}$ & $\pm \mathrm{ND}$ & $\pm \mathrm{ND}$ & $\pm \mathrm{ND}$ & $\pm \mathrm{ND}$ & $\pm \mathrm{ND}$ \\
\hline \multirow{2}{*}{ W23sfe4 } & \multirow{2}{*}{ stem } & 0.064 & 0.092 & 0.138 & $0.195 \mathrm{ab}$ & 0.278 & 0.052 & 0.192 & 0.072 & 1.082 \\
\hline & & \pm 0.009 & \pm 0.017 & \pm 0.019 & \pm 0.009 & \pm 0.018 & \pm 0.004 & \pm 0.023 & \pm 0.008 & \pm 0.098 \\
\hline \multirow{2}{*}{$\mathrm{W} 23 s f e 21$} & \multirow{2}{*}{ stem } & 0.074 & 0.106 & 0.143 & $0.201 \mathrm{a}$ & 0.280 & 0.047 & 0.167 & 0.087 & 1.102 \\
\hline & & \pm 0.004 & \pm 0.003 & \pm 0.005 & \pm 0.003 & \pm 0.052 & \pm 0.008 & \pm 0.003 & \pm 0.009 & \pm 0.034 \\
\hline
\end{tabular}

${ }^{\dagger}$ Samples were composites from the replicated field trial reported by Jung and Phillips (2010). Equal amounts of dried plant material for each maize line and plant part from each field plot $(\mathrm{N}=4)$, location $(\mathrm{N}=2)$, and year $(\mathrm{N}=2)$ were combined to create the samples analyzed in the current study. See Table 1 for definition of FA dimer labels. "Standard errors were calculated for the duplicate laboratory analyses done on each sample. For comparison of W23 with the two mutant lines within plant parts different letters indicate differences at the $\mathrm{p}<0.1$ level. For W23 stem material, one of the replicate subsamples was lost during the analysis and, therefore, the mean is based on only one lab subsample analysis.

Table 4. Concentration (mean \pm 1 standard error) of etherified diferulates in cell wall material from leaf blade, sheath, and stem mature stover fractions of the maize inbred line W23, and the near-isogenic low ferulate W23sfe4 and W23sfe21 mutant lines. ${ }^{\dagger}$

\begin{tabular}{|c|c|c|c|c|c|c|c|c|c|c|}
\hline \multirow[b]{2}{*}{ Line } & \multirow{2}{*}{$\begin{array}{c}\text { Plant } \\
\text { Tissue }\end{array}$} & \multicolumn{9}{|c|}{$\underline{\text { Etherified Diferulates }}$} \\
\hline & & $8-8 \mathrm{nc}$ & $8-8 c$ & $8-5 \mathrm{nc}$ & $8-O-4$ & 8-5benz & $t 8-5 \mathrm{nc}$ & $8-5 \mathrm{dc}$ & $5-5$ & Total \\
\hline & & \multicolumn{9}{|c|}{ 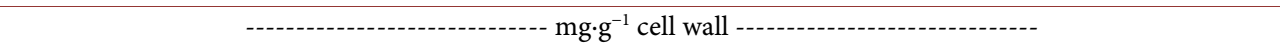 } \\
\hline \multirow{2}{*}{ W23 } & \multirow{2}{*}{ leaf } & $0.029 \mathrm{a}$ & $0.081 \mathrm{a}$ & 0.083 & 0.073 & 0.096 & 0 & 0.082 & $0.164 \mathrm{a}$ & 0.606 \\
\hline & & \pm 0 & \pm 0.002 & \pm 0.028 & \pm 0.027 & \pm 0.029 & \pm 0 & \pm 0.026 & \pm 0.002 & \pm 0.106 \\
\hline \multirow{2}{*}{ W23sfe4 } & \multirow{2}{*}{ leaf } & $0.011 b$ & $0.054 \mathrm{~b}$ & 0.053 & 0.063 & 0.070 & 0 & 0.043 & $0.087 \mathrm{c}$ & 0.379 \\
\hline & & \pm 0.003 & \pm 0.007 & \pm 0.010 & \pm 0.012 & \pm 0.012 & \pm 0 & \pm 0.008 & \pm 0.003 & \pm 0.024 \\
\hline \multirow{2}{*}{ W23sfe21 } & \multirow{2}{*}{ leaf } & $0.011 b$ & $0.058 \mathrm{~b}$ & 0.062 & 0.060 & 0.045 & 0 & 0.051 & $0.122 \mathrm{~b}$ & 0.408 \\
\hline & & \pm 0.001 & \pm 0.012 & \pm 0.019 & \pm 0.019 & \pm 0.019 & \pm 0 & \pm 0.018 & \pm 0.006 & \pm 0.092 \\
\hline \multirow{2}{*}{ W23 } & \multirow{2}{*}{ sheath } & 0.016 & 0.088 & 0.113 & 0.097 & 0.105 & 0 & 0.088 & $0.160 \mathrm{ab}$ & 0.666 \\
\hline & & \pm 0.004 & \pm 0.029 & \pm 0.047 & \pm 0.040 & \pm 0.053 & \pm 0 & \pm 0.031 & \pm 0.010 & \pm 0.213 \\
\hline \multirow{2}{*}{ W23sfe4 } & \multirow{2}{*}{ sheath } & 0.018 & 0.129 & 0.119 & 0.123 & 0.110 & 0 & 0.091 & $0.225 a$ & 0.814 \\
\hline & & \pm 0.008 & \pm 0.060 & \pm 0.043 & \pm 0.004 & \pm 0.012 & \pm 0 & \pm 0.042 & \pm 0.032 & \pm 0.200 \\
\hline \multirow{2}{*}{ W23sfe21 } & \multirow{2}{*}{ sheath } & 0.017 & 0.070 & 0.093 & 0.087 & 0.088 & 0 & 0.068 & $0.133 b$ & 0.553 \\
\hline & & \pm 0.004 & \pm 0.034 & \pm 0.031 & \pm 0.025 & \pm 0.021 & \pm 0 & \pm 0.025 & \pm 0.020 & \pm 0.159 \\
\hline \multirow{2}{*}{ W23 } & \multirow{2}{*}{ stem } & 0.023 & 0.063 & 0.255 & 0.070 & 0.186 & 0 & 0.124 & 0.170 & 0.891 \\
\hline & & $\pm \mathrm{ND}^{\ddagger}$ & $\pm \mathrm{ND}$ & $\pm \mathrm{ND}$ & $\pm \mathrm{ND}$ & $\pm \mathrm{ND}$ & $\pm \mathrm{ND}$ & $\pm \mathrm{ND}$ & $\pm \mathrm{ND}$ & $\pm \mathrm{ND}$ \\
\hline \multirow{2}{*}{ W23sfe4 } & \multirow{2}{*}{ stem } & 0.017 & 0.066 & 0.133 & 0.071 & 0.099 & 0 & 0.077 & 0.112 & 0.572 \\
\hline & & \pm 0.007 & \pm 0.034 & \pm 0.049 & \pm 0.025 & \pm 0.026 & \pm 0 & \pm 0.025 & \pm 0.021 & \pm 0.186 \\
\hline \multirow{2}{*}{ W23sfe21 } & \multirow{2}{*}{ stem } & 0.022 & 0.047 & 0.119 & 0.079 & 0.092 & 0 & 0.053 & 0.162 & 0.574 \\
\hline & & \pm 0.010 & \pm 0.018 & \pm 0.016 & \pm 0.012 & \pm 0.017 & \pm 0 & \pm 0.024 & \pm 0.021 & \pm 0.116 \\
\hline
\end{tabular}

${ }^{\dagger}$ Samples were composites from the replicated field trial reported by Jung and Phillips (2010). Equal amounts of dried plant material for each maize line and plant part from each field plot $(\mathrm{N}=4)$, location $(\mathrm{N}=2)$, and year $(\mathrm{N}=2)$ were combined to create the samples analyzed in the current study. See Table 1 for definitions of FA dimer labels. ${ }^{*}$ Standard errors were calculated for the duplicate laboratory analyses done on each sample. For comparison of W23 with the two mutant lines within plant parts different letters indicate differences at the $\mathrm{p}<0.1$ level. For W23 stem material, one of the replicate subsamples was lost during the analysis and, therefore, the mean is based on only one lab subsample analysis. 
<smiles>COc1cc(C=CC(=O)PC)ccc1O</smiles>

1 (Ferulate)<smiles>COc1cc(C=C(C(=O)O)/C(=C/c2ccc(O)c(OC)c2)C(=O)O)ccc1O</smiles><smiles>COc1cc([C@H]2c3cc(O)c(OC)cc3C=C(C(=O)O)[C@H]2C(=O)O)ccc1O</smiles>

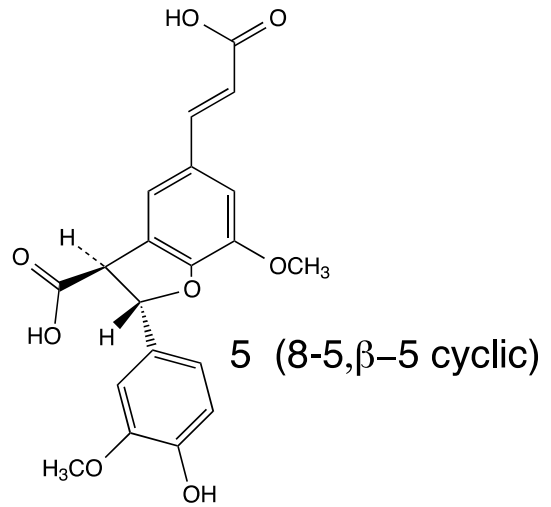<smiles>COc1cc(/C=C/c2cc(/C=C/C(=O)O)cc(OC)c2O)ccc1O</smiles>

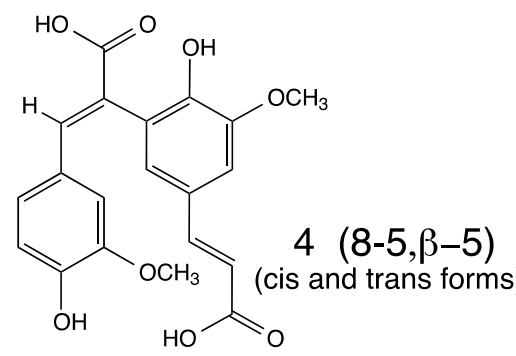
(cis and trans forms)<smiles>COc1cc(/C=C(/Oc2ccc(/C=C/C(=O)O)cc2OC)C(=O)O)ccc1O</smiles>

$6(8-5, \beta-5)$

(Decarboxylation product)<smiles>COc1cc(/C=C/C(=O)O)cc(-c2cc(/C=C/C(=O)O)cc(OC)c2O)c1O</smiles>

$8(5-5)$<smiles>COc1cc(/C=C/C(=O)O)ccc1Oc1cc(/C=C/C(=O)O)cc(OC)c1O</smiles>

Figure 2. Chemical structures of released dehydrodimers formed between ferulates in the cell walls of grasses. The designation listed in the illustration identifies the bond that can be formed between two carbons or a carbon and oxygen atom. A single ferulate molecule (1) is included along with the numbering scheme for phenolic compounds. The following list identifies the ferulate dimer that can be found in grass cell walls (refers to abbreviations in Table 3 and Table 4 followed by the number of the molecule in illustration 1): 8-8 noncyclic, 8-8nc (2); 8-8 cyclic, 8-8c (3); 8-5 cis and trans forms, 8-5 (4); 8-5 cyclic form, 8-5 benz (5); 8-5 decarboxylated, $8-5 \mathrm{dc}(6) ; 8-O-4(7) ; 5-5(8)$. It is possible to form a 4-O-5 (9) but this does not appear to happen frequently and were not detected in these samples. 
dependent upon the amount of FA incorporated into a given tissue and not upon some control mechanism resulting in one DFA type over another. Linkages between ferulates and lignin that are not susceptible to hydrolysis by high temperature alkaline treatment are possible and would not be analyzed with the methods described [9] [37].

\subsection{Cell Wall Carbohydrates}

Concentration of total carbohydrates making up cell walls was different among the tissues (leaf $<$ sheath $\approx$ stem). Comparing sfe mutants to W23 within a given tissue revealed variation with no consistent trend of increased or decreased amounts (Table 1). Neutral sugar composition of cell walls did not reflect differences that were the result of the sfe mutation except for the arabinosyl (Ara) content of sheaths in W23sfe21 (Supplementary Table 1). Molar concentrations of xylose (Xyl) in cell walls were essentially the same within tissue types and only small differences when comparing different tissue types (average leaf 40.6, sheath 36.4, and stem 37.9 Supplementary Table 1). Likewise, glucose (Glc) did not appear to be significantly impacted by the sfe mutation ( 45.6 to $54.5 \mathrm{~mol} 100$ $\mathrm{mol}^{-1}$ total cell wall or a $16.3 \%$ difference across all tissues with stems having the highest concentration (Supplementary Table 1). Previous reports also found no impact of the sfe mutation on glucose concentrations [18] [19]. The molar concentration of Ara varied from tissue to tissue more than the other major cell wall neutral sugars (stem < leaves < sheaths, 4.9 to $13.9100 \mathrm{~mol}^{-1}$ total cell wall or a difference of 65\%). One might expect the Ara levels to remain relatively constant within each tissue when comparing W23 to W23sfe4 and W23sfe21 if the mutation is impacting only the total ferulates. The highest levels of Ara were in the sheath tissue corresponding to the highest levels of total ferulates. Leaf tissues contained the next highest level of Ara, but contained the lowest level of total ferulates. Stem tissues had Ara levels approximately half that of the sheaths with total ferulates more closely resembling sheaths. Within a given tissue, the molar ratio of Ara remained relatively unchanged except for W23sfe21 that had a 28\% increase in Ara (Supplementary Table 1). This is also the one tissue that increased in total ferulates (Table 1). If the Ara remains relatively constant within a given tissue (W23 vs $s f e$ ) the Ara:FA ratio should increase if there is a decrease in total ferulates. This was the case for leaf tissue where total ferulate substitution on Ara residues decrease from approximately one in five (W23) to one in six (W23sfe4) and one in nearly seven (W23sfe21) (Table 5). This is also true for the stems though changes were not as prominent (Table 5). Sheath tissue showed the largest change in Ara:FA ratio for W23sfe21. One would have expected the ratio to decrease due to higher amounts of total ferulates in these walls. In this case, the ratio increased to 8 compared to 6 for W23 and W23sfe4. This was also the one tissue that had an increase in Ara incorporated into the cell walls (Supplementary Table 1). Apparently the increase in Ara offset the small increase in total ferulates in this tissue resulting in a Ara:FA ratio of 8. 
Table 5. A comparison of total ferulates to arabinose within maize cell walls. Total ferulates includes both ester and ether link monomers and dehydrodiferulates. As an additional comparison, molar ratio of xylose to arabinose is given to indicate possible changes in cell wall composition.

\begin{tabular}{cccc}
\hline & & \multicolumn{2}{c}{ Molar Ratio } \\
\hline Line & Plant Tissue & Ara/FA & Xyl:Ara \\
\hline W23 & leaf & 5.23 & 5.03 \\
W23sfe4 & leaf & 6.17 & 5.10 \\
W23sfe21 & leaf & 6.77 & 5.17 \\
W23 & sheath & 6.40 & 3.46 \\
W23sfe4 & sheath & 6.15 & 3.55 \\
W23sfe21 & sheath & 8.52 & 2.48 \\
W23 & stem & 3.29 & 7.75 \\
W23sfe4 & stem & 3.51 & 7.26 \\
W23sfe21 & stem & 3.91 & 7.09 \\
\hline
\end{tabular}

The ratio Xyl:Ara gives an indication of the relative level of Ara substitution on the xylan polymers incorporated into the cell wall. This in turn provides an indication of how components may interact or associate within the cell wall matrix [38]. The Xyl:Ara ratios were different when comparing one tissue type to another (Table 5). Sheath tissues had the most highly branched arabinoxylans, on average one mole of Ara for every 3.2 moles of Xyl with stems having the least branched with one Ara for every 7.4 moles of Xyl. Leaf tissue ratios were intermediate with one Ara for every five Xyl residues. W23sfe21 sheath tissue had the lowest ratio with approximately two Ara for every five Xyl residues (2:5). Stem tissues showed a decrease in Xyl:Ara comparing W23 to W23sfe4 and W23sfe21 indicating a slightly higher substitution of Ara upon the xylan backbone. Levels of substitution of Ara on xylans could alter how these polysaccharides interact with other wall polysaccharides especially cellulose. Less substitution would allow greater amounts of hydrogen bond formation creating a more tightly bound arabinoxylan. Although these ratios give an indication of how the matrix may look in terms of both total ferulate and Ara substitution, the ratios do not infer an even distribution within the cell wall matrix. It is more likely that ferulates are clustered in regions to help insure sufficient cross-linking takes place to create required structural integrity. Small statistically significant changes in molar ratios of key wall components were observed in the earlier study with sfe mutants [18] [19]. It was suggested that the sfe mutation actually impacted synthesis of the entire ferulate-arabinoxylan complex [18] [19]. The results from the current study would support this conclusion as Ara and total ferulates did not seem to be fluctuating independently of each other. 


\subsection{Cell Wall Lignin and $p$-Coumarates}

As observed in previous studies there were changes in lignin and $p$-coumarate components of the cell wall apparently in response to the sfe mutation compared to W23 [18] [19]. Lignin as measured by the acetyl bromide assay was lower in W23sfe4 and W23sfe21 leaf tissue compared to the W23. Sheath and stem tissue also showed reductions in lignin for the sfe mutant lines, but not as pronounced. The average lignin concentration for the sfe mutants in leaf tissue was approximately $14 \%$ less than the lignin in W23 whereas the sheath and stem sfe mutants were only $4 \%$ and $7 \%$ lower respectively. Because the acetyl bromide assay accounts for all cell wall bound phenolics it is possible the reductions in ferulates (Table 1) could contribute to a reduction in total absorbance and thus less apparent lignin. Changes in lignin concentration reported earlier exhibited different trends [18]. Both Klason and acid detergent lignin concentrations in leaves were minimally ( $0 \%$ to $2 \%$ reductions) impacted by the sfe mutation, whereas both lignin measures indicated larger (5\% to $36 \%$ reductions) effects of the mutation on sheath and stem tissues. However, whole plant maize silage did not show consist changes in Klason or acid detergent lignin due to thesfe mutation [19]. The largest changed in lignin from the previous study was in ADL analysis of stem tissues (11\% and $36 \%$ for sfe4 and sfe21 respectively). It is known that acid detergent will solubilize lignin especially in grass species [24] [39]. Perhaps the cell wall modifications in the sfe mutants, though small, are enough to impact the solubility of the lignin fraction in hot detergent solution. Altering the amount of ferulate cross-linking to lignin (both as FA and DFA, Table 2) could change the solubility of these complexes in hot acid detergent allowing more to be washed out of the sfe mutant cell walls. Subtle changes in the cell wall organization may account for the improvements in cell wall digestibility of these corn mutants [19]. We have proposed that ferulates may play an important role in the organization of grass cell walls [40] and perturbations in this organization could be sufficient to change lignin interactions without causing large changes in biomass production.

Analysis of isolated cell walls using 2D-NMR evaluation of W23, W23sfe4 and W23sfe21 clearly show differences among the tissues (leaf vs sheath vs stem) for the major lignin and phenolic components (Figure 3). Determining differences in ferulates and $p$ CA between W23 and the sfe mutations is difficult due the relatively small changes in these two wall components based on chemical analysis. NMR techniques as used in this study with whole cell walls should account for all ferulates even those that are not readily released by normal ester and ether hydrolysis techniques. The formation of ether-linked ferulate within grass cell walls is not the only type of bond to cross-link the cell wall matrix [9]. Other bonds (e.g., C-C) can also form and would not be released by typical methods used to release ether type bonds. However, all of these ferulates should be visible in the 2D-NMR spectra. Since there is no internal standard applied to these cell walls it is not possible to quantify subtle changes in composition such as ferulates 


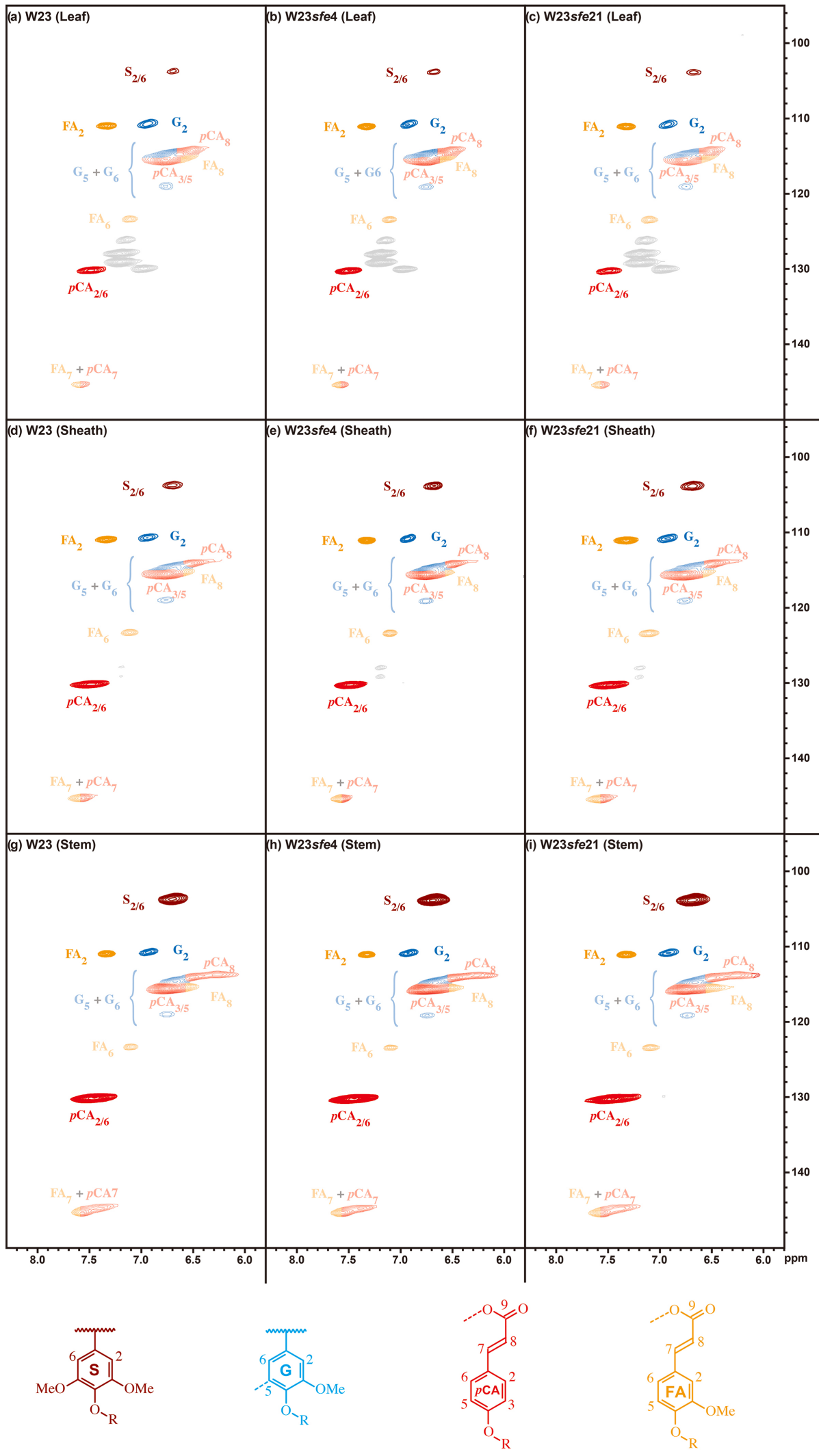

Figure 3. 2D-NMR spectra of phenolic rich region including lignin, total ferulates, and p-coumarates in cell walls of maize leaf, sheath and stem tissues. Figure components are color coded to show major response signals of lignin and cell wall phenolics, illustrated at the bottom of the figure. Abbreviations: $\mathrm{S}=$ syringyl units; $\mathrm{G}=$ guaiacyl units; $p \mathrm{CA}=p$-coumarate; $\mathrm{FA}=$ ferulates. 
in stem tissue of W23 compared to sfe mutations. Differences among tissue types are readily identified in the NMR spectra (Figure 3). The use of 2D-NMR allows highly accurate comparisons of constitutes that make up a given polymer such as lignin to determine lignin composition i.e., S:G values [29]. In addition, the ratio of FA:pCA based upon chemical data compared to $2 \mathrm{D}-\mathrm{NMR}$ indicated similar ratios within a given tissue type (Table 6). The FA:pCA is not as robust perhaps as the $S: G$ values because there is not a good way to account for variations in the amount of material that is being analyzed by NMR techniques. This ratio provides an indication of relative changes to each other. For sheath and stem tissues the ratio of FA:pCA were nearly the same when comparing chemical based data with the information obtained from 2D-NMR analysis of these same tissues. One might expect if total ferulates were decreasing due to the mutation within a given tissue the ratio would decrease as long as total $p C A$ levels remain unchanged. Based on the results of this study FA: $p C A$ did not change even though there were small decreases in the total ferulates measured (Table 6, Table 1). The lack of change in the ratio would be indicative of either no changes in these components or decreases in $p \mathrm{CA}$ to offset any change in the total FA in the cell walls of the mutants. The latter case appears to be what is happening suggesting that the sfe mutation is influencing more than simple ferulate incorporation into cell wall matrices.

Plants containing the sfe mutation had altered lignin concentration (Table 1), but there did not appear to be consistent results in terms of lignin composition. A comparison of three methods for assessing composition (nitrobenzene oxidation, total cell wall 2D-NMR analysis, and pyrolysis) provided similar results for most of the tissues at least in terms of the trends within a tissue comparing W23 to the sfe mutant lines. One would expect 2D-NMR and pyrolysis to perhaps

Table 6. Comparison of total ferulates with total $p$-coumarates as a ratio of FA to $p C A$. Values were based upon alkaline hydrolysis using low temperature for ester linked and high temperature for ether linked phenolics and NMR of total cell wall components using 2D-NMR analysis.

\begin{tabular}{cccc}
\hline & & \multicolumn{2}{c}{ FA:pCA } \\
\hline Line & Plant Tissue & Chemical & 2D-NMR \\
\hline W23 & leaf & 1.15 & 1.43 \\
W23sfe4 & leaf & 1.06 & 1.23 \\
W23sfe21 & leaf & 1.12 & 1.67 \\
W23 & sheath & 1.06 & 0.99 \\
W23sfe4 & sheath & 1.05 & 0.90 \\
W23sfe21 & sheath & 1.15 & 1.07 \\
W23 & stem & 0.35 & 0.34 \\
W23sfe4 & stem & 0.32 & 0.30 \\
W23sfe21 & stem & 0.35 & 0.32 \\
\hline
\end{tabular}


provide the most similar results, as these two methods should theoretically evaluate all of the components within a given tissue. Pyrolysis is dependent upon the pyrolytic efficiency of the compounds within the tissues undergoing analysis. It is assumed these should be the same from one tissue to the next for lignin although it is not known if changes in lignin composition could change this efficiency as measured by the recovered products. For $2 \mathrm{D}-\mathrm{NMR}$ a limitation may be in sensitivity. Although the technique is quite sensitive to changes in chemical components that make up the cell wall it is limited by the total concentration of any one component under analysis. The changes in absolute amounts of total ferulates, $p C A$ or lignin components may be difficult to accurately determine by NMR. Nitrobenzene oxidation on the other hand, due to the nature of the chemical reaction, does not result in a complete breakdown of the lignin. The release of components is dependent upon the amount of lignin and the chemical bonds that make up the lignin structure. There did not appear to be large changes in lignin composition due to the sfe mutation. For the stem tissues there appeared to be an increase in $S: G$ as a response to the sfe mutation (Table 7). All three techniques revealed the same trends although the magnitude of the change was different depending upon the individual technique.

Typically, there is a relatively strong, positive correlation between total lignin and total $p$-coumarates ( $p \mathrm{CA}$ ) in grass cell walls [41] [42] [43]. Levels of $p \mathrm{CA}$ were different when comparing the maize tissues (Table 1). Within each tissue type leaf, sheath, and stem, there was small but consistent decreases in $p C A$ between the sfe mutants and W23 (Table 1). One would expect if the sfe mutation impacts ferulate incorporation into the cell wall $p C A$ levels would remain unchanged. There was a small amount of $p \mathrm{CA}$ measured in the ether-linked category

Table 7. Lignin composition comparison of syringyl units to guaiacyl units an S:G ratio basis. Values were based upon nitrobenzene oxidation, NMR of total cell wall components using 2D-NMR analysis, and pyrolysis of total cell wall isolated from different tissue.

\begin{tabular}{ccccc}
\hline & & \multicolumn{3}{c}{ S:G } \\
\hline Line & Plant Tissue & Nitrobenzene & 2D-NMR & ${ }^{2}$ Pyrolysis \\
\hline W23 & leaf & 0.67 & 0.29 & 0.94 \\
W23sfe4 & leaf & 0.53 & 0.29 & 0.86 \\
W23sfe21 & leaf & 0.80 & 0.32 & 0.86 \\
W23 & sheath & 0.49 & 0.51 & 0.70 \\
W23sfe4 & sheath & 0.62 & 0.51 & 0.69 \\
W23sfe21 & sheath & 0.99 & 0.65 & 0.70 \\
W23 & stem & 1.22 & 1.23 & 1.28 \\
W23sfe4 & stem & 1.40 & 1.29 & 1.35 \\
W23sfe21 & stem & 1.40 & 1.33 & 1.46 \\
\hline
\end{tabular}

${ }^{a}$ Data from Jung and Phillips (2010). 
of hydroxycinnamates suggesting there may be additional linkages this molecule was also undergoing. It is more likely that a more aggressive alkaline treatment would be needed to swell the matrix and release these more recalcitrant $p C A$ ester molecules. Jung and Phillips [18] had reported less esterified $p C A$ in all three plant parts for the sfe mutant; however, analysis of whole maize silage did not indicate a difference [19].

\section{Conclusion}

The maize sfe mutants resulted in changes within the cell wall matrices including a reduction in total ferulate cross-linking within the cell walls and reductions in lignin. Ether linked ferulates to lignin were reduced more consistently in the sfe mutants. These data support the earlier indirect measurements reported [18] [19]. Ether linked ferulates were reduced between $14 \%$ and $26 \%$ depending upon the tissue. Leaf tissues demonstrated the largest decreases in ether-linked ferulates both as FA and as DFA. The formation of DFA and cross linkages to lignin would presumably be the most critical factors impacting cell wall digestibility and animal performance [11] [12]. Although the changes in cross-linking were modest, they were sufficient to result in significantly improved animal performance without sacrificing total biomass production [18] [19]. It is difficult to say that the changes in ferulates are the only factor in this study resulting in improved digestibility as other subtle changes occurred in structural elements of the total cell wall matrix (e.g., lignin). These could have an additive effect resulting in improved animal performance without the need for large shifts in cell wall composition.

\section{Specific Products}

Mention of a proprietary product does not constitute a recommendation or warranty of the product by USDA or the University of Minnesota, and does not imply approval to the exclusion of other suitable products.

\section{References}

[1] Kato, Y. and Nevins, D.J. (1985) Isolation and Identification of O-(5-O-feruloyl- $\alpha$-l-arabinofuranosyl)-1 $\rightarrow 3$ )-O- $\beta$-d-xylopyranosyl-(1 $\rightarrow 4)$-d-xylopy ranose as a Component of Zea Shoot Cell-Walls. Carbohydrate Research, 137, 139-150. https://doi.org/10.1016/0008-6215(85)85155-7

[2] Ishii, T. and Hiroi, T. (1990) Linkage of Phenolic Acids to Cell-Wall Polysaccharides of Bamboo Shoot. Carbohydrate Research, 206, 297-310. https://doi.org/10.1016/0008-6215(90)80069-F

[3] Ishii, T. and Hiroi, T. (1990) Isolation and Characterization of Feruloylated Arabinoxylan Oligosaccharides from Bamboo Shoot Cell Walls. Carbohydrate Research, 196, 175-183. https://doi.org/10.1016/0008-6215(90)84117-D

[4] Ralph, J., Quideau, S., Grabber, J.H. and Hatfield, R.D. (1994) Identification and Synthesis of New Ferulic Acid Dehydrodimers Present in Grass Cell Walls. Journal of the Chemical Society, Perkin Transactions, 1, 3485-3498. https://doi.org/10.1039/p19940003485 
[5] Grabber, J.H., Hatfield, R.D., Ralph, J., Zon, J. and Amrhein, N. (1995) Ferulate Cross-Linking in Cell Walls Isolated from Maize Cell Suspensions. Phytochemistry, 40, 1077-1082. https://doi.org/10.1016/0031-9422(95)00413-2

[6] Bunzel, M., Funk, C., Dobberstein, D., Steinhart, H. and Ralph, J. (2007) Ferulate Trimers and Tetramers in Cereal Grains. Euro Food Chem 14th Conference, Paris, 29-31 August 2007.

[7] Bunzel, M., Ralph, J., Funk, C. and Steinhart, H. (2005) Structural Elucidation of New Ferulic Acid-Containing Phenolic Dimers and Trimers Isolated from Maize Bran. Tetrahedron Letters, 46, 5845-5850. https://doi.org/10.1016/j.tetlet.2005.06.140

[8] Ralph, J., Helm, R.F., Quideau, S. and Hatfield, R.D. (1992) Lignin-Feruloyl Ester Cross-Links in Grasses. Part 1. Incorporation of Feruloyl Esters into Coniferyl Alcohol Dehydrogenation Polymers. Journal of the Chemical Society, Perkin Transactions, 1, 2961-2969. https://doi.org/10.1039/P19920002961

[9] Ralph, J., Grabber, J.H. and Hatfield, R.D. (1995) Lignin-Ferulate Crosslinks in Grasses: Active Incorporation of Ferulate Polysaccharide Esters into Ryegrass Lignins. Carbohydrate Research, 275, 167-178. https://doi.org/10.1016/0008-6215(95)00237-N

[10] Grabber, J.H., Ralph, J., Hatfield, R.D., Quideau, S., Kuster, T. and Pell, A.N. (1996) Dehydrogenation Polymer-Cell Wall Complexes as a Model for Lignified Grass Walls. Journal of Agricultural and Food Chemistry, 44, 1453-1459. https://doi.org/10.1021/jf9502717

[11] Grabber, J.H., Hatfield, R.D. and Ralph, J. (1998) Diferulate Cross-Links Impede the Enzymatic Degradation of Nonlignified Maize Walls. Journal of the Science of Food and Agriculture, 77, 193-200. https://doi.org/10.1002/(SICI)1097-0010(199806)77:2<193::AID-JSFA25>3.0.CO;2-A

[12] Grabber, J.H., Ralph, J. and Hatfield, R.D. (1998) Ferulate Cross-Links Limit the Enzymatic Degradation of Synthetically Lignified Primary Walls of Maize. Journal of Agricultural and Food Chemistry, 46, 2609-2614. https://doi.org/10.1021/jf9800099

[13] Jung, H.G. and Casler, M.D. (1991) Relationship of Lignin and Esterified Phenolics to Fermentation of Smooth Bromegrass Fibre. Animal Feed Science and Technolo$g y$, 32, 63-68. https://doi.org/10.1016/0377-8401(91)90010-P

[14] Casler, M.D. and Jung, H.G. (1999) Selection and Evaluation of Smooth Bromegrass Clones with Divergent Lignin and Etherified Ferulic Acid Concentration. Crop Science, 39, 1866-1873. https://doi.org/10.2135/cropsci1999.3961866x

[15] Piston, F., Uauy, C., Fu, L.H., Langston, J., Labavitch, J. and Dubcovsky, J. (2010) Down-Regulation of Four Putative Arabinoxylan Feruloyl Transferase Genes from Family PF02458 Reduces Ester-Linked Ferulate Content in Rice Cell Walls. Planta, 231, 677-691. https://doi.org/10.1007/s00425-009-1077-1

[16] Buanafina, M.M., Fescemyer, H.W., Sharma, M. and Shearer, E.A. (2016) Functional Testing of a PF02458 Homologue of Putative Rice Arabinoxylan Feruloyl Transferase Genes in Brachypodium distachyon. Planta, 243, 659-674. https://doi.org/10.1007/s00425-015-2430-1

[17] Mitchell, R.A.C., Dupree, P. and Shewry, P.R. (2007) A Novel Bioinformatics Approach Identifies Candidate Genes for the Synthesis and Feruloylation of Arabinoxylan. Plant Physiology, 144, 43-53. https://doi.org/10.1104/pp.106.094995

[18] Jung, H.G. and Phillips, R.L. (2010) Putative Seedling Ferulate Ester (sfe) Maize Mutant: Morphology, Biomass Yield, and Stover Cell Wall Composition and Rumen 
Degradability. Crop Science, 50, 403-418.

https://doi.org/10.2135/cropsci2009.04.0191

[19] Jung, H.G., Mertens, D.R. and Phillips, R.L. (2011) Effect of Reduced Ferulate-Mediated Lignin/Arabinoxylan Cross-Linking in Corn Silage on Feed Intake, Digestibility, and Milk Production. Journal of Dairy Science, 94, 5124-5137. https://doi.org/10.3168/jds.2011-4495

[20] Hatfield, R.D. (1992) Carbohydrate Composition of Alfalfa Cell Walls Isolated from Stem Sections Differing Maturity. Journal of Agricultural and Food Chemistry, 40, 424-430. https://doi.org/10.1021/jf00015a012

[21] Hatfield, R.D., Wilson, J.R. and Mertens, D.R. (1999) Composition of Cell Walls Isolated from Cell Types of Grain Sorghum Stems. Journal of the Science of Food and Agriculture, 79, 891-899.

https://doi.org/10.1002/(SICI)1097-0010(19990501)79:6<891::AID-JSFA304>3.0.CO ;2-\#

[22] Hatfield, R.D. and Marita, J.M. (2017) Maize Development: Cell Wall Changes in Leaves and Sheaths. American Journal of Plant Science, 8, 1248-1263. https://doi.org/10.4236/ajps.2017.86083

[23] Saeman, J.F., Moore, W.E. and Millett, M.A. (1963) Sugar Units Present. In: Whistler, C.R.L., Ed., Hydrolysis and Quantitative Paper Chromatography, Academic Press, New York, 54-69.

[24] Hatfield, R.D., Jung, H.G., Ralph, J., Buxton, D.R. and Weimer, P.J. (1994) A Comparison of the Insoluble Residues Produced by the Klason Lignin and Acid Detergent Lignin Procedures. Journal of the Science of Food and Agriculture, 65, 51-58. https://doi.org/10.1002/jsfa.2740650109

[25] Blakeney, A.B., Harris, P.J., Henry, R.J. and Stone, B.A. (1983) A Simple and Rapid Preparation of Alditol Acetates for Monosaccharide Analysis. Carbohydrate Research, 113, 291-299. https://doi.org/10.1016/0008-6215(83)88244-5

[26] Hatfield, R.D., Grabber, J.H., Ralph, J. and Brei, K. (1999) Using the Acetyl Bromide Assay to Determine Lignin Concentrations in Herbaceous Plants: Some Cautionary Notes. Journal of Agricultural and Food Chemistry, 47, 628-632. https://doi.org/10.1021/jf9808776

[27] Fukushima, R.S. and Hatfield, R. (2004) Comparison of the Acetyl Bromide Spectrophotometeric Method with Other Analytical Lignin Methods for Determining Lignin Concentration in Forage Samples. Journal of Agricultural and Food Chemistry, 52, 3713-3720. https://doi.org/10.1021/jf0354971

[28] Fukushima, R.S. and Hatfield, R.D. (2001) Extraction and Isolation of Lignin for Utilization as a Standard to Determine Lignin Concentration using the Acetyl Bromide Spectrophotometric Method. Journal of Agricultural and Food Chemistry, 49, 3133-3139. https://doi.org/10.1021/jf010449r

[29] Kim, H. and Ralph, J. (2010) Solution-State 2D NMR of Ball-Milled Plant Cell Wall Gels in DMSO- $\mathrm{d}_{6} /$ Pyridine- $_{5}$. Organic \& Biomolecular Chemistry, 8, 576-591. https://doi.org/10.1039/B916070A

[30] Kim, H. and Ralph, J. (2014) A Gel-State 2D-NMR Method for Plant Cell Wall Profiling and Analysis: A Model Study with the Amorphous Cellulose and Xylan from Ball-Milled Cotton Linters. RSC Advances, 2014, 7549-7560. https://doi.org/10.1039/C3RA46338A

[31] Kupce, E. and Freeman, R. (2007) Compensated Adiabatic Inversion Pulses: Broadband INEPT and HSQC. Journal of Magnetic Resonance, 187, 258-265. https://doi.org/10.1016/j.jmr.2007.05.009 
[32] Ishii, T. (1991) Isolation and Characterization of a Diferuloyl Arabinoxylan Hexasaccharide from Bamboo Shoot Cell-Walls. Carbohydrate Research, 219, 15-22. https://doi.org/10.1016/0008-6215(91)89039-I

[33] Bunzel, M., Ralph, J., Brüning, P. and Steinhart, H. (2006) Structural Identification of Dehydrotriferulic and Dehydrotetraferulic Acids Isolated from Insoluble Maize Fiber. Journal of Agricultural and Food Chemistry, 54, 6409-6418. https://doi.org/10.1021/jf061196a

[34] Bunzel, M., Ralph, J., Marita, J.M., Hatfield, R.D. and Steinhart, H. (2001) Diferulates as Structural Components in Soluble and Insoluble Dietary Fibre. Journal of the Science of Food and Agriculture, 81, 653-660. https://doi.org/10.1002/jsfa.861

[35] Dobberstein, D. and Bunzel, M. (2010) Separation and Detection of Cell Wall-Bound Ferulic Acid Dehydrodimers and Dehydrotrimers in Cereals and Other Plant Materials by Reversed Phase High-Performance Liquid Chromatography with Ultraviolet Detection. Journal of Agricultural and Food Chemistry, 58, 8927-8935. https://doi.org/10.1021/jf101514j

[36] Hatfield, R.D. and Ralph, J. (1999) Modeling the Feasibility of Intramolecular Dehydrodiferulate Formation in Grass Walls. Journal of the Science of Food and Agriculture, 79, 425-427.

https://doi.org/10.1002/(SICI)1097-0010(19990301)79:3<425::AID-JSFA282>3.0.CO $\underline{; 2-\mathrm{U}}$

[37] Ralph, J., Hatfield, R.D., Grabber, J.H., Jung, H.G., Quideau, S. and Helm, R.F. (1998) Cell Wall Cross-Linking in Grasses by Ferulates and Diferulates. In: Lewis, N.G. and Sarkanen, S., Eds., Lignin and Lignan Biosynthesis, American Chemical Society, Washington DC, 209-236. https://doi.org/10.1021/bk-1998-0697.ch016

[38] Carpita, N.C. and Whittern, D. (1986) A Highly Substituted Glucuroarabinoxylan from Developing Maize Coleoptiles. Carbohydrate Research, 146, 129-140. https://doi.org/10.1016/0008-6215(86)85030-3

[39] Lowry, J.B., Conlan, L.L., Schlink, A.C. and McSweeney, C.S. (1994) Acid Detergent Dispersible Lignin in Tropical Grasses. Journal of the Science of Food and Agriculture, 65, 41-49. https://doi.org/10.1002/jsfa.2740650108

[40] Hatfield, R.D., Rancour, D.M. and Marita, J.M. (2016) Grass Cell Walls: A Story of Cross-Linking. Frontiers in Plant Science, 7, 2056.

[41] Hatfield, R.D., Marita, J.M. and Frost, K. (2008) Characterization of p-Coumarate Accumulation, p-Coumaroyl Transferase, and Cell Wall Changes during the Development of Corn Stems. Journal of the Science of Food and Agriculture, 88, 2529-2537. https://doi.org/10.1002/jsfa.3376

[42] Hatfield, R.D., Marita, J.M., Frost, K., Grabber, J., Ralph, J., Lu, F.C. and Kim, H. (2009) Grass Lignin Acylation: p-Coumaroyl Transferase Activity and Cell Wall Characteristics of C3 and C4 Grasses. Planta, 229, 1253-1267.

https://doi.org/10.1007/s00425-009-0900-Z

[43] Hatfield, R.D. and Chaptman, A.K. (2009) Comparing Corn Types for Differences in Cell Wall Characteristics and p-Coumaroylation of Lignin. Journal of Agricultural and Food Chemistry, 57, 4243-4249. https://doi.org/10.1021/jf900360z 


\section{Supplementary}

Table 1. Composition (mean \pm 1 standard error) of the cell wall carbohydrates from leaf blade, sheath, and stem mature stover fractions of the maize inbred line W23, and the near-isogenic low ferulate W23sfe4 and W23sfe21 mutant lines. ${ }^{\dagger}$

\begin{tabular}{|c|c|c|c|c|c|c|c|c|}
\hline \multirow[b]{2}{*}{ Line } & \multirow{2}{*}{$\begin{array}{c}\text { Plant } \\
\text { Part }\end{array}$} & \multicolumn{7}{|c|}{ Cell Wall Carbohydrates $^{*}$} \\
\hline & & Glc & Xyl & Ara & Gal & Man & Rha & Fuc \\
\hline & \multicolumn{8}{|c|}{ - } \\
\hline W23 & leaf & $46.3 \pm 0.1$ & $41.3 \pm 0.3$ & $8.2 \pm 0.3$ & $2.8 \pm 0.1$ & $0.7 \pm 0$ & $0.6 \pm 0.04$ & $0.1 \pm 0.02$ \\
\hline W23sfe4 & leaf & $48.0 \pm 0.1$ & $39.9 \pm 0.1$ & $7.8 \pm 0.2$ & $2.6 \pm 0.05$ & $0.9 \pm 0.01$ & $0.6 \pm 0.02$ & $0.1 \pm 0.01$ \\
\hline $\mathrm{W} 23 s f e 21$ & leaf & $47.4 \pm 0.05$ & $40.5 \pm 0.3$ & $7.8 \pm 0.1$ & $2.6 \pm 0.05$ & $1.0 \pm 0.02$ & $0.6 \pm 0.02$ & $0.1 \pm 0.01$ \\
\hline W23 & sheath & $46.7 \pm 0.1$ & $37.6 \pm 0.04$ & $10.9 \pm 0.1$ & $3.5 \pm 0.02$ & $0.7 \pm 0$ & $0.5 \pm 0.02$ & $0.1 \pm 0.02$ \\
\hline W23sfe4 & sheath & $48.8 \pm 0.3$ & $36.3 \pm 0.01$ & $10.2 \pm 0.2$ & $3.3 \pm 0.1$ & $0.7 \pm 0.01$ & $0.6 \pm 0.03$ & $0.1 \pm 0.01$ \\
\hline $\mathrm{W} 23 s f e 21$ & sheath & $45.6 \pm 0.7$ & $35.4 \pm 2.4$ & $13.9 \pm 2.8$ & $3.9 \pm 0.5$ & $0.6 \pm 0.1$ & $0.5 \pm 0.1$ & $0.2 \pm 0.01$ \\
\hline W23 & stem & $54.5 \pm 0.5$ & $38.2 \pm 0.2$ & $4.9 \pm 0.2$ & $1.2 \pm 0.03$ & $0.5 \pm 0.02$ & $0.6 \pm 0.01$ & $0.1 \pm 0.01$ \\
\hline $\mathrm{W} 23 s f e 4$ & stem & $54.4 \pm 0.6$ & $37.7 \pm 0.1$ & $5.2 \pm 0.3$ & $1.5 \pm 0.1$ & $0.6 \pm 0.04$ & $0.5 \pm 0.02$ & $0.1 \pm .07$ \\
\hline $\mathrm{W} 23 s f e 21$ & stem & $54.3 \pm 0.4$ & $37.8 \pm 0.1$ & $5.3 \pm 0.2$ & $1.3 \pm 0.1$ & $0.5 \pm 0.02$ & $0.6 \pm 0.02$ & $0.1 \pm 0.01$ \\
\hline
\end{tabular}

${ }^{\dagger}$ Samples were composites from the replicated field trial reported by Jung and Phillips (2010). Equal amounts of dried plant material for each maize line and plant part from each field plot $(\mathrm{N}=4)$, location $(\mathrm{N}=2)$, and year $(\mathrm{N}=2)$ were combined to create the samples analyzed in the current study. ${ }^{*} \mathrm{Glc}$, glucose; Xyl, xylose; Ara, arabinose; Gal, galactose; Man, mannose; Rha, rhamnose; Fuc, fucose. 